\title{
Shanti Swarup Bhatnagar, Working through/against the Colonial System
}

\author{
Robert Anderson* \\ (Received 18 April 2018; revised 17 May 2018)
}

\begin{abstract}
Shanti Swarup Bhatnagar was unusual in the scientific community of twentieth century India, perhaps unique. His behaviour tested the 'default settings' of the political and administrative system in which he lived and worked, as shown here in three examples from his life. Constrained by those settings like everyone else, he nevertheless found an entrepreneurial space in which he could experiment with innovations. He was a leader with an ego, but also seems to have been an enabler, still able to identify promise in others. Although he was deep in the rules of the system, he does not appear to have been a blocker of other peoples' potential. Bhatnagar was, when we see him in these three situations, usually in transition from one state [in the chemical sense] to another. He was polyvalent, combining and acting with quite difference forces. He seems never to have been trapped in a binary set of oppositions, at least not for long. He was a sign, in the semiotic sense, which could be read in two or three different ways. All this made him an intermediary leader in the building of scientific institutions for the scientific community, channeling the energies and resources of the colonial system through the hands of the builders, some of whom he had picked himself. But what kind of leader was Bhatnagar in the last stage of his life?
\end{abstract}

Key words: Atomic energy, Bhabha, Chemistry and chemists, Coerseduction, Colonial 'system', CSIR, Delhi, Entrepreneurial space, Hegemony, IISc, Intermediary leader, Lahore, London rules, National laboratories, Raman, Saha.

\section{INTRODUCTION}

Three brief dramas of Shanti Swarup Bhatnagar's professional life show us that the operational environment he had to address in 'the colonial system' was not the same thing in 1922 , in 1932, nor in 1942. Whatever it was, it was evolving rapidly. The focus here is on (a) Bhatnagar's competition for the job of director of a special chemical laboratory at Lahore; (b) the contest, involving Bhatnagar, at Bangalore over the future of CV Raman in the director's office at the Indian Institute of Science (IISc) Bangalore, ${ }^{1}$; and (c) his role in developing the atomic energy program from 1944, long before there was a clear picture of Britain's withdrawal from power in India.
But first some background is relevant. We know that Shanti Swarup Bhatnagar was born into a relatively poor family in 1894 , and moved to Lahore for schooling at age fourteen, in fact the same school his father had attended. Since his father had died when Shanti was born, and his mother lived far away, he was now on his own. Soon he attended Dyal Singh College, founded by Brahmo Samaj followers, and he set up a little chemistry lab under the stairs of the college. He soon moved up to Forman Christian College. Being an excellent student, his Brahmo relationship eventually made him eligible for a Dyal Singh scholarship to study abroad. At that point, in 1918-19, he was moving fluently in a

\footnotetext{
* Simon Fraser University, Burnaby, Canada, Email: robert_anderson@sfu.ca

1 Note; spellings here (eg Bangalore, Bombay) are spellings commonly accepted at that time. It is understood that many of these names have been modified.
} 
multi-cultural world of Hindu reform movements, Christian educational institutions, and Muslim reformers - all in a great city planned in the Mughal style, with its unique literature, architecture, and poetry. ${ }^{2}$ We have no evidence as to what he thought about the crushing force available to the colonial 'system', though he surely would have been well aware of the 1919 Jallianwala Bagh massacre which occurred nearby in Amritsar, in which British soldiers shot hundreds of people trapped in a walled garden. ${ }^{3}$ In the absence of his personal letters and private poetry, we only can speculate on the effects of these cultural influences, in the same way as astro-physicists must speculate on the effects of dark energy. ${ }^{4}$

\section{Bhatnagar, the Boy}

At age seven, on New Year's morning of 1900, Bhatnagar stepped into a new century. We will examine how the system appeared to him, and how he was drawn along the path to London in 1920. That was where no one in his family lineage had ever dreamed of going. But this is not just about the young Bhatnagar, but should be generalized to millions of young people all across India, on the first day of the twentieth century. Where did the sciences and their objectives and methods, and scientists and their institutions, fit in when the century opened in 1900? First, we must remember that the British had conveyed gradually but decisively to India and Indians the very means of communication which had made the empire possible. The language and the technologies associated with its expression and spread were available in India after the eighteenth century, evolving to printing and then books in the early nineteenth. Nothing was withheld, and the situation was irreversible; poetics, theatre, polemics, propaganda, books on chemistry, the practice of medicine, etc. were all available and transmitted among a growing elite. Even banned material achieved underground samizdat notoriety, and circulated quickly and quietly. By 1900 science, medicine, and engineering were paths on which Indians could compete and excel, and be taken seriously across the world. A seven year old was capable of beginning to learn about that by age fourteen, and Bhatnagar was drawn towards it as a teenager and carried onward to maturity. Besides, by 1915 he was twenty one, just married, and needed to work.

The British and European presence in India invited, inspired, and then required Indian participation in all these communicative activities. In a parallel path very close to those kinds of engagement which I have just listed, the system itself needed Indians who were skilled in observing, recording, chronicling, weighing, mapping, accounting, measuring - all the ingredients which enabled the Government of India to begin 'seeing like a state' (Scott, 1998). Of course princely states including the great Mughal emperors at Delhi and Agra had been doing this in India long before, but now British and European ways were engaged in a forced blending with those previous practices, and the combination became very effective. Emphasis on these skills and outlooks provided some suggestive openings, particularly when a few Britons and Indians agreed to develop a new kind of activity called 'doing science together'. Indians saw that these skills and this knowledge were defined as professions with good names drawing respect from other Indians, and respect from Europeans with both rank and status. These professions offered reasonable rewards (doctor, chemist, etc). So being a scientist and practicing

\footnotetext{
2 Lahore became a science-friendly city. Bhatnagar plus many others flourished there; there were eventually three Nobel Prize physicists who once lived in Lahore - Har Gobind Khoranna, S. Chandrasekhar, Abdus Salam.

3 A more detailed account of Bhatnagar's life is found in my Nucleus and Nation, 2010.

4 Some of Bhatnagar's papers which were being kept in the CSIR system appear to have been accidentally destroyed, which is why we are unable to explain these cultural influences. There may also be closed files held in various departments, and unseen papers in the Maulana Azad files in the National Archives.
} 
or teaching science drew people seductively in and drew them onward. This was the path which Bhatnagar followed.

But could 'doing science together' assist in the project of colonial domination? Of course it could. And could doing science probably assist the 'system' in establishing hegemony? Perhaps, some Britons thought in 1900, if new science and new technology were part of a wider effort involving language, law, and values, then 'doing science together' would add to the hegemonic effort. ${ }^{5}$ Bhatnagar's dramas here show that not all Britons in India were equally committed to the hegemonic project: some behaved as if they intended to undermine hegemony (Kumar \& McLeod, 1995). And when political and social movements chose to confront the forceful face of British power it appears that most sections of the scientific community were offered an alternate non-confrontational path, because scientists were becoming valued in India. Bhatnagar mostly followed that non-confrontational path.

These currents were flowing when Bhatnagar stepped into the twentieth century at age seven. A small scientific community in Lahore nurtured his curiosity as a teenager, in a college founded by American missionaries, and a scientific profession appeared dimly before him in the distance. He followed a new path which led him to London 20 years later, supported by a scholarship established by his father's Brahmo reform movement. There he studied colloids with a famous British chemistry professor who had nothing to do with India or the Rāj, although F G Donnan was already famous in munitions research, a subject which was very strategic in India. ${ }^{6}$ Donnan had already achieved his FRS and was being given an award for war-time research as Bhatnagar arrived in 1920. In all those twenty years from 1900 to 1920 Bhatnagar showed no particular interest in the British effort to establish hegemony. This was in sharp contrast, for example, to Meghnad Saha whom he first met in London, exactly his age-mate. Saha had already been expelled from school in Dacca and barred from writing the 1916 civil service exams due his political 'disobedience'.

The uses of force, although kept in the background, were brought forward occasionally to crush and coercively remind Indians of their obligation to comply. Meanwhile there was steady effort to construct an effective hegemony, although it achieved its effects mostly among middle classes and elites, and very few others. Ranajit Guha called it a 'spurious hegemony' (1998); I would call it an 'elusive' hegemony. Aside from developing new science and technology, the colonial rules were also deeply embedded in the relation of the pound and the rupee, taxes and tariffs, trading limitations, university examinations and court procedures, and endless administrative regulations from which, quoting from $16^{\text {th }}$ century Spain, we get the famous term 'red tape'. Although the whole resulting system was unstable, it still managed to perpetuate itself even without establishing hegemony.

We have seen in this collection how the rules of the political economy of the imperial system were supposed to apply to the specific situation in India. Because they were rather variable in their application, the rules did not appear in precisely the same way at each place and each time. The whole context exhibited the quality of 'coerseduction', which both attracted

\footnotetext{
5 The effort allocated to establishing British hegemony, an effort which never quite succeeded, was after all much lower in cost that the crushing use of force, which was also available and used occasionally.

${ }^{6}$ Colloids are both inorganic and organic (mud oils 1935 vegetable oils 1943) - solid like coloured glass, gaseous like smoke. Colloids are one of three kinds of similar mixtures, the other two being solutions and suspensions. Bhatnagar himself is a mixture like a colloid. Such a mixture! SSB's interests and eclectic identities (scientist, Lahore, conscientious member of his Hindu caste but very comfortable in Muslim culture) Brahmo Samaj, Dayal Singh scholarship, Foreman Christian College, Urdu poet, friendship with Maulana Azad.
} 
attention and stimulated promise while requiring compliance. ${ }^{7}$ This complex 'double-bind' quality of the colonial system influenced scientists, such as Bhatnagar and Saha, differently. This is how we should understand Bhatnagar's relations with his colleagues in the 1920s and 1930s. He would not have functioned so successfully without those colleagues, even those who opposed him. They were becoming the scientific community. That is what these three dramas from Bhatnagar's life show us. ${ }^{8}$

\section{The Early Bhatnagar}

He studied almost by accident with F G Donnan a famous British chemistry professor who had nothing to do with India or the Rāj. After completing his DSc at the University of London in 1920 and spending a research sojourn at labs in Germany (in Saha's company) during the following year, Bhatnagar landed a good teaching position at Benares Hindu University; he had elite backing (J C Bose, P C Ray, C V Raman all recommended him). From this base in Benares he then competed successfully for his first big job as director of the Chemical Laboratories at the University of Punjab in 1923. He was in competition with an incumbent acting-director, but the committee chose Bhatnagar, not the British incumbent. The rules of the colonial 'system', at that time, were that the British candidate, who had been acceptable before Bhatnagar's arrival, should prevail (in game terms, he should 'trump'). Bhatnagar might, under the same rules, have been induced or advised to withdraw his candidacy and wait a bit until the next opportunity. ${ }^{9}$ However he did not withdraw, and his bold move yielded a successful appointment by a committee which was bending the rules. Thus lucky timing played an important role that then opened an unexpected path toward his applied research with Steel Brothers petroleum unit in 1933, and that is how he founded a new Department of Petroleum Research at University of Punjab in Lahore, using a gift from Steel Brothers; with those funds he also founded a group of 'Bhatnagar Scholarships'. Thus began Bhatnagar's comfortable relation with foreign capital, a relation which deepened during the coming war, but a relation which was contested over and over again. ${ }^{10}$

\section{The Mid-life Bhatnagar}

Bhatnagar's role in the formal reviews of the IISc at Bangalore began in 1930, when he was thirty six. He had begun to associate himself with Sir P C Ray and his large network which included activist-chemists like N R Dhar (Mazumdar, 2018), using the Science Congress meetings as the diplomatic opportunity for these contacts; it was probably Ray, already on the Governing Council, who nominated Bhatnagar for a role in

\footnotetext{
Coerseduction is a term created by Rene-Jean Ravault, a Canadian communication scholar in Montreal; the relevant citations are "Resisting Media Imperialism by Coerseduction" in INTERMEDIA, 13.3 (1984):32-37; also "Colonialisme culturel et coerseductions autochtones" in "la Revue Internationale de Science Politique/International review of Political Science", (1986):251-280.

8 I chose 'dramas' because of his love of the theatre and acting.

9 This episode differs from the one twenty years earlier, described by Arnab Rai Choudhuri and Rajinder Singh (2018), in which geologist T.H. Holland was appointed Director of the Geological Survey of India in 1903, chosen instead of the older and more accomplished Pramata Nath Bose. This position in Calcutta was much more prestigious and influential than the lab directorship in Lahore, so was more likely to be contested. P N Bose "resigned in protest"; see Choudhuri and Singh 2018, p 63. The passage of twenty years probably explains part of the difference in outcome, as 1923 and 1903 were very different operating environments. The impact of the recent war on British demography meant that five years after the war, in 1923, there were fewer young candidates for positions in India coming from the UK.

${ }^{10}$ Steel Brothers was a profitable Burma-based company in oil, timber, and rice, benefitting from this new collaboration in India, so they were, in an enlightened way, investing in their future in India by making regular contributions to the university in Bhatnagar's name. This paid off in 1942 when Steel Brothers suddenly sought refuge in India as Japanese forces occupied all the company's facilities in Burma. (Anderson, Nucleus and Nation, p. 601 n.680).
} 
Bangalore. During the routine assessment of Director C V Raman's role there in 1936-37 there emerged a confrontation between high-level institutional policies and colonial actors like the Viceroy and Lord Ernest Rutherford of Cambridge. The Institute itself was in conflict about the relations of physical chemistry and physics, and about its leadership and intellectual future; the current director was due to retire. Bangalore's population was divided on the question of Raman's plans for chemistry and physics for what was then called 'the Tata Institute'. This was a battle of "The Knights", because all of them in the late 1930s were sirs, James Irvine, C V Raman, and P C Ray (Bhatnagar himself would soon be a knight too, in less than two years). But only one of these people had won a Nobel Prize, and that person was a big problem for the IISc's Council. Bhatnagar was learning crisis diplomacy in the 'late colonial period'. He saw the high status of the powerful Tata family, he saw the keenness of the Viceroy to stay out of this disagreement, and the concern of Rutherford to fix it. There was both a public face and private face for this conflict: it culminated with the Council's decision to end Raman's directorship but offer him again his previous position as professor of physics, a decision in which Bhatnagar participated. Raman was furious, and asked for Rs $100,000 /$ in severance payment, but there is no evidence that this sum (which amounted to two year's salary) was actually paid. ${ }^{11}$ Bhatnagar became very mobile across India in 1936-39, and developed a national reputation. But his poetic heart was in Lahore: we should read his poetry to know his heart's imaginings, fantasies, disappointments, fears; that is the Bhatnagar we do not know.

\section{The Mature Bhatnagar}

Bhatnagar said he believed in liberation through science and technology, and that meant cooperation and open-ness, not secrecy; during the planning process of 1938-40 he talked about 'progress', so he seems to have imagined a future which did not require coercion and force, in common with Nehru. Up to 1942 his cooperation with Indian nationalists was manageable but from 1942 the Non- Cooperation Movement was outlawed and Congress leaders were imprisoned: because Bhatnagar was a government official he had to stand aside and continue to do his job. But what was his job really like?

In 1940 he moved from Lahore to Delhi to become an upper-level government official, and then moved immediately to Calcutta in 1941 to start the Council of Scientific and Industrial Research (CSIR). In 1942, Bengal was becoming 'a police state' due to its militarization following the Japanese invasion of Burma and during the Quit India movement. In 1943, he moved back to Delhi from Calcutta where he had been eyewitness to the colonial government's incompetent management of the Bengal Famine. He was still attracted to a scientific state, strong and yet cooperative. But we simply do not know about his views and role in surveillance and accountability, of which he was necessarily a key part. In 1944, he would be working in an environment in which secrecy was normal practice. This was a coercive aspect of the colonial 'system' in which he was becoming a key player.

India became a major productive and defensive zone after 1942, especially in 1943 and 1944 when the Japanese forces closed in on the Indian border. Bhatnagar believed cooperation between nationalists and the British imperial system was possible and said the war proved that. In 1946, he listed the types of products, all essential to war in Asia and Europe, which had been developed and proto-typed in CSIR labs, bringing considerable profits to the Council.

\footnotetext{
${ }^{11}$ See Nucleus and Nation pp 71-74 for a complete account; these notes here are based on copies of Minutes of IISc meetings found in the files of chemist P C Ray, who was also a member of the Council.
} 
As he entered his 'late period' (remember he died young at 60) we should ask if he was cultivating a new leadership group? He was already maneuvering in late 1946 to have K S Krishnan become director of the National Physical Laboratory (NPL), (Malik, 2012, pp. 274-75), and identified Salimuzzaman Siddiqui to be appointed leader of the National Chemical Laboratory (NCL) in early 1947. Now he advocated Indian skill development, gradual Indianization through institution-building, nevertheless accepting foreigners in leadership positions (e.g. in the director's office in the labs for Glass \& Ceramics, National Chemical Laboratory into the 1950s).

Bhatnagar was named Director General of the CSIR and Secretary of the new Ministry of Natural Resources and Science in 1947, and became the top assistant to its minister Maulana Azad. ${ }^{12} \mathrm{He}$ was already on the Council of the new Tata Institute for Fundamental Research being planned in Bombay. He remained on the Governing Council of the IISc in Bangalore (until his other duties overwhelmed him). So Bhatnagar was a key player in the prolonged 'post-colonial' transition; it stretched well into the $1950 \mathrm{~s} .{ }^{13}$ His role in the building of the two really big labs, the NCL (1950) and the NPL (1951) is well known and celebrated in a stamp depicting him and the lab (Fig. 1); those two eventually lead to CSIR labs in metallurgy, aeronautics, glass and ceramics; 22 research \& development labs in all. ${ }^{14}$ This alone is astonishing.

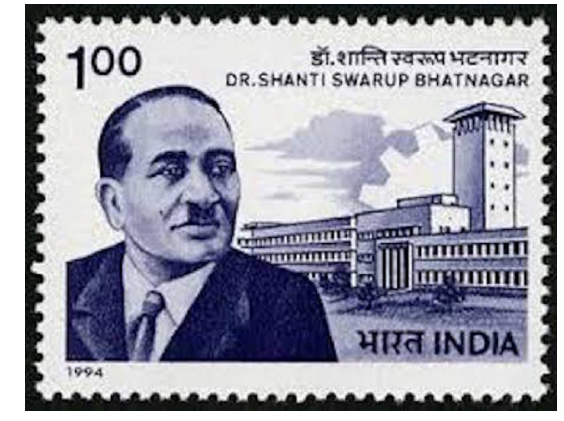

Fig. 1. The 1993 postage stamp depicting Bhatnagar and the NPL; ' although the National Chemical Laboratory near Pune was equally important to Bhatnagar, the NPL's location on the northern edge of Delhi meant he could show it to Nehru and other leaders frequently and conveniently. He knew others wanted the job as NPL's director but maneuvered to have KS Krishnan appointed. All the other CSIR labs were widely dispersed, so difficult to show off to passing leaders.' (source: Indian Postal Service).

But his role in Natural Resources \& Science took Bhatnagar deeper into key strategic commodities, namely oil/petroleum and thorium. This was far beyond his knowledge of oil extraction in the Attock district of Punjab in the 1930s. ${ }^{15}$ Starting in 1947-48 he began to learn about new oil exploration techniques, gained knowledge of petroleum extraction systems, pipelines, refineries, and mass product distribution. ${ }^{16}$ Maulana Azad did not understand industrial chemistry, but he was ready to become Bhatnagar's channel to Nehru and the Cabinet. Their pleasure in the Urdu language and its poetry must have made communication much easier.

\footnotetext{
${ }^{12}$ Given the life-expectancy of Indian males at the time, it would not have been surprising [to others] that Bhatnagar died at age sixty.

${ }^{13}$ For example non-Indian chemists (first an American, followed by a Briton), with strong international credentials, were directors of the NCL (about which Bhatnagar cared greatly) through 1957. Bhatnagar's colleague, organic chemist Salimuzzaman Siddiqui had been appointed NCL director in early 1947, long before the new lab at Poona was built, but this appointment was not to last. The unfortunate story of what happened to Siddiqui after partition is reported in Nucleus and Nation, pp 156-158.

${ }^{14}$ I have learned about the NPL history through the pioneering work of Shiv Visvanathan, and Bhatnagar's writings through V.V. Krishna. Conversations with them, and others, while I was a visiting fellow at NISTADS in 2005 in Delhi, and subsequently, were most important.

${ }^{15}$ He worked with refugees as a volunteer for the Red Cross in both cities, and lost his Lahore house.

${ }^{16}$ I think a study of that work, including the involvement of the Russians and Americans in the oil business, would be very important part of India's technical and industrial history.
} 


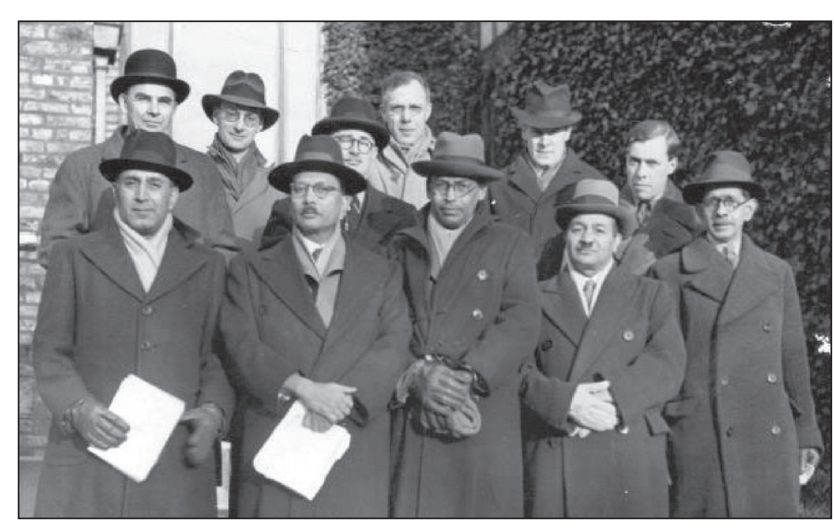

Fig. 2. Bhatnagar \& Co in London December 1944 on goodwill mission, touring strategic Allied laboratories in UK, Canada, and USA including Manhattan Project sites. Shown [left-right] are Nazir Ahmed, Jnan Ghosh, Meghnad Saha, Shanti Bhatnagar, Jnan Mukherjee; others behind are unknown. Not shown are tour members physicist SK Mitra, and SL Bhatia, physician. Bhatnagar and Saha were questioned by the FBI after visiting one of those Manhattan Project sites. (Courtesy of Saha Institute and Jahnavi Phalkey])

But Bhatnagar also had another separate role starting three years before independence, starting in 1944. That role is little known and really worth exploring here. We know that the Quebec Agreement between the UK and USA and Canada identified thorium in India as strategically important to their war effort and post-war efforts too. The demand for Indian thorium went up when the US bombs were dropped on Japan after 1945. But ten months before August 1945, Bhatnagar was among a small group of Indian scientists touring secret Manhattan Project facilities and planning for their own nuclear future (Fig. 2). In fact Bhatnagar was the official team leader, responsible for others, all physicists and chemists by training. That is why Bhatnagar and team member Meghnad Saha were questioned by the FBI in Washington in February 1945 after Saha had asked very pertinent questions about one of the Manhattan facilities, questions which put the American experts on guard.
The background to this tour began in August 1943 when Churchill and Roosevelt met Mackenzie King at Quebec and signed a "Declaration of Trust" intended, among other objectives, to "insure the acquisition at the earliest practicable moment an adequate supply of uranium and thorium ores", and to gain control and develop production of thorium located, among other places, in India. The process of seizing and securing all uranium in Canada was also already under way. The inclusion of India's thorium seemed the next logical step. ${ }^{17}$ At that time Bhatnagar had just been awarded his FRS, and was privately talking with Archibald Hill about a tour of nuclear facilities, although Nehru and other Congress leaders were in prison. All this was being approved by the Viceroy's Council. ${ }^{18}$

The well-known determination of the British PM Churchill to retain the structure of the empire was not shared by either the Canadian Prime Minister or the US President. The British were being given a 'sphere of interest' in thorium in India in this Declaration, and when this interest devolved to India in 1947 Homi Bhabha, Bhatnagar, and geologist D N Wadia were already engaged in negotiations for thorium in Travancore. Indians were asserting some sovereignty in India while the British were preoccupied with their transition. But still the British desired this sphere for their secret weapons program, as we learn from 1948 British files: thorium's importance and value was increasing steadily. The Americans and French had also been sniffing around India's thorium deposits. Bhatnagar knew India had limited hydro-power and oil potential. He was familiar with burning coal to make electricity, but how long could that be sustained? So along with their geological exploration for uranium which yielded nothing until 1951-52, India's atomic committee needed a sure thing to bargain with.

\footnotetext{
${ }^{17}$ Margaret Gowing, Britain and Atomic Energy 1965; (see full text of the declaration, p.444-446).

${ }^{18}$ Which Indians, if any, knew about the secret declaration, or about the specific provisions for thorium is something I don't know.
} 


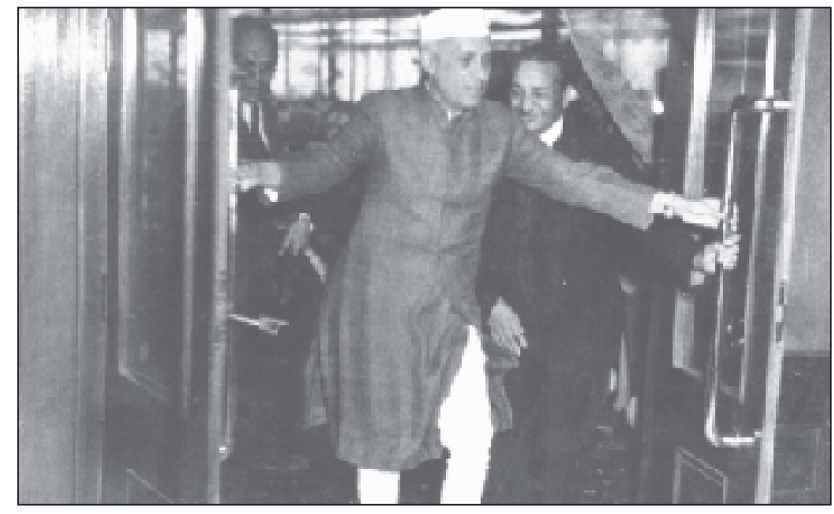

Fig. 3. Nehru walking through new door at the National Chemical Laboratory Pune in 1951, followed closely by Shanti Bhatnagar. Bhatnagar's choice of the lab's first director in 1947, Salimuzzaman Siddiqui, could not continue in this prestigious and sensitive role after 1948 when his brother, a prominent leader, left for Pakistan. (Source: National Chemical Laboratory website)

Bhatnagar, Bhabha, and others realized that the sure thing would be thorium. ${ }^{19}$

The early Atomic Energy Committee 1945-1947, of which Bhatnagar became Secretary, was centered in Bombay and bound Bhatnagar to unusual partners (Bhabha and Saha), and compelled him to mediate between those two opposites. He committed part of his CSIR budget to the purposes of the Atomic Energy Committee. Thus his 'colonial research council', which was already committed to 'big science' projects like the chemistry lab and physics lab, was also enabling the start-up of the Atomic Energy Commission well before India was an independent state. As early as August-September 1945 he authorized an Indian scientist to travel to Nagasaki and Hiroshima to survey the effects of the atomic bomb, accompanying Allied scientists. ${ }^{20}$ These facts were known to senior British administrators.

Bhatnagar now entered a world of strategic commodities, oil, heavy water, uranium, thorium,

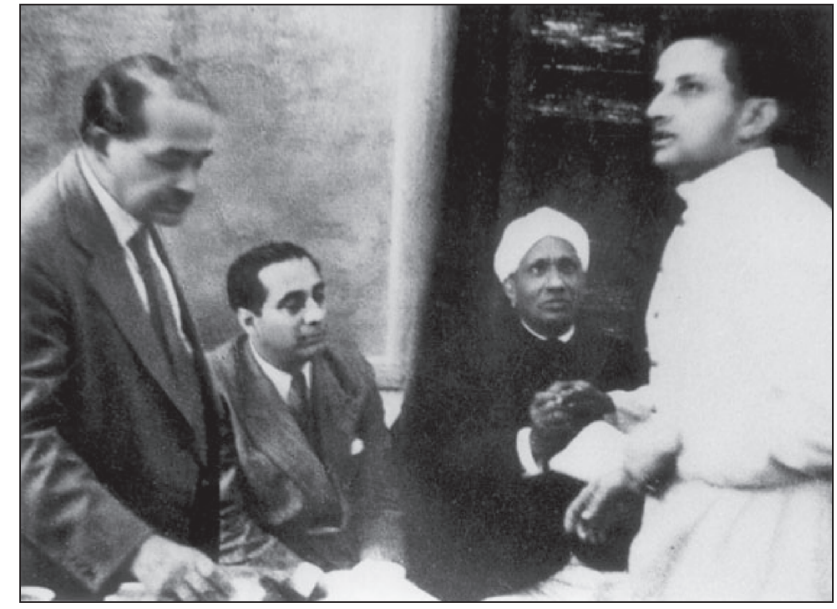

Fig. 4. Bhatnagar (standing, left) in Ahmedabad in 1952, with Homi Bhabha and CV Raman, at the new physical research laboratory being built by Vikram Sarabhai (standing, right). Thirty three year old Sarabhai was defined as Raman's student, eventually succeeding Bhabha as leader of the atomic energy and space programs. (Courtesy of Physical Research Laboratory Ahmedabad)

etc. He was the secretary for a ministry involved in 'natural resources'. His earlier inside-government patrons like Arcot Ramaswamy Mudaliar and Ardeshir Dalal, both knights, retired; but Nehru became his new patron. He asked Bhatnagar to tour the thorium sands of Travancore in January 1947, together with Bhabha, and this put Bhatnagar squarely in the middle of a struggle between US and UK interests, and India's new government well before independence. Nehru's advisor and UK physicist Sir Patrick Blackett also struck up a friendly relation with Bhatnagar, and they toured both CSIR labs and defense production units together. Bhatnagar was active in this role until his sudden death on the last night of 1954. For example he joined Bhabha in 1952 encouraging the creation of a new physics research centre in Ahmedabad. For example he was included in the meetings convened by Nehru at his residence in September and November 1954 to plan India's

\footnotetext{
${ }^{19}$ Some of this interpretation is found in Nucleus and Nation, pp 191, n691. For greater detail on Travancore see also Itty Abraham 2011.

${ }^{20}$ S. Parthasarathi was the physicist, and we know about this site-inspection only because he wrote in 1952 to Patrick Blackett about his enquiry that was carried out in late 1945; the full citation is in Nucleus and Nation, p187.
} 
participation in the forthcoming Peaceful Uses of Atomic Energy conference at Geneva. With all his positions and roles in 1947-1948, was Bhatnagar becoming a 'big tree' under which little could grow? Six years later, on the last night of 1954, Bhatnagar died suddenly, without warning, and thus opened a very large space in the landscape of the political Indian scientists.

\section{ACKNowledgement}

I gratefully acknowledge conversations with all the participants at the March 2018 conference at INSA Delhi which stimulated this special issue: the articles contained in this issue have positively influenced my thinking about Bhatnagar's wider context.

\section{BiBLIOGRAPHY}

Abraham, Itty. Rare Earths: the Cold War in the Annals of Travancore in Gabrielle Hecht (ed.) Entangled Geographies: Empire and Technopolitics in the Global Cold War, MIT Press, 2011.

Anderson, Robert. Nucleus and Nation: International Networks, Scientists, and Power in India, University of Chicago Press, 2010.

Choudhuri, Arnab Rai and Singh Rajinder. The FRS Nomination of Sir Prafulla C Ray and Correspondence of N R Dhar, Notes and Records of the Royal Society, 72 (2018):57-73.

Gowing, Margaret. Britain and Atomic Energy 1939-1945, Macmillan, London, 1965.

Guha, Ranajit. Dominance without Hegemony: History and Power in Colonial India, Harvard University Press, 1998.

Krishna, V V. S.S. Bhatnagar on Science, Technology, and Development, Wiley Eastern, Delhi 1993.

Kumar, Deepak and Roy Mcleod. Technology and the Raj: Western Technology and Technical Transfers to India 1700-1947, Sage, Delhi, 1995.

Mallik, D C V and Chatterjee, Sabyasachi. Kariamanikkam Srinivasa Krishnan: His Life and Work, Universities Press, Hyderabad, 2012.

Mazumdar, Madhumita. Reflecting on Chemical Education: Nilratan Dhar and the legacy of P C Ray, Indian Journal of History of Science, 53.4 (2018) T94-T99.

Ravault, Rene-Jean. Resisting Media Imperialism by Coerseduction, INTERMEDIA Vol. 13 no. 3 (1984):3237.

Ravault, Rene-Jean. Colonialisme culturel et coerseductions autochtones in la Revue Internationale de Science Politique/International review of Political Science, 1986, pp. 251-280.

Scott, James. Seeing Like a State, Yale University Press, 1998.

Visvanathan, Shiv. Organizing for Science, Oxford University Press, Delhi, 1984. 